Research article

\title{
RECLASSIFICATION OF 21 PRESUMPTIVE CANINE PERIPHERAL NERVE SHEATH TUMORS (PNST) USING A LITERATURE-BASED IMMUNOHISTOCHEMICAL PANEL
}

\author{
SIRRI Rubina, SABATTINI Silvia, BETTINI Giuliano, MANDRIOLI Luciana* \\ Department of Veterinary Medical Sciences, University of Bologna, Via Tolara di Sopra 50, \\ Ozzano dell'Emilia, Bologna, Italy
}

(Received 08 July; Accepted 18 October 2016)

\begin{abstract}
The aim of this study was to re-evaluate archived samples of canine soft tissue sarcomas (STSs) morphologically consistent with peripheral nerve sheath tumors (PNSTs). In each case, an immunohistochemical panel was applied, including $\alpha$-SMA, calponin, desmin, S-100, GFAP, NSE and Olig2, in order to assess whether the phenotype was consistent with the tumor histological appearance. Additionally, the expression of EGFR, a marker with potential therapeutic implications in malignant PNSTs, was evaluated. Twenty-one tumors were included. Fourteen cases $(66.7 \%)$ were positive for one or more muscular markers and were reclassified as perivascular tumors (PWTs). A positive labeling for S-100 was observed in one tumor (4.8\%), thus classified as PNST. The other 6 tumors were generically classified as poorly differentiated STSs. No unique histopathological feature was observed within the three groups. NSE and Olig2 labeling was aspecific and not useful for diagnostic purposes. GFAP was negative in all cases. Six cases $(28.6 \%)$ were positive for EGFR, including the PNST. Even after the application of a wide immunohistochemical panel, distinguishing between PNSTs and PW'Ts remains a challenge. Finally, a subgroup of cases cannot be classified based on light microscopy alone.
\end{abstract}

Key words: canine; EGFR; immunohistochemistry; PNST; soft tissue sarcomas

\section{INTRODUCTION}

Peripheral nerve sheath tumors (PNSTs) are a heterogeneous group of neoplasms originating from either Schwann cells, modified Schwann cells, intraneural fibroblasts or perineural cells [1-3].

Histologically, they are composed of spindle-shaped cells with ovoid, fusiform or serpentine nuclei, arranged in wavy bundles, nuclear palisades, whorls or storiform fascicles. This pattern is referred to as Antoni type A. In veterinary medicine the formation of Verocay bodies, characterized by a double row of palisading tumor cells,

\footnotetext{
*Corresponding author: e-mail: luciana.mandrioli@unibo.it
} 
is rarely observed. Additionally, tumors may contain areas with loosely-packed tumor cells distributed in a fibrillary to mucinous matrix, referred to as Antoni type B pattern [4]. Based on cellular morphology, mitotic activity and tumor invasion, they are further subclassified as benign (BPNST) or malignant (MPNST) [3,5].

PNSTs may occur also in soft tissue and, occasionally, in visceral organs [6-9].

Canine cutaneous peripheral nerve sheath tumors can generate diagnostic problems because of the histopathological similarities with other spindle cell tumors, including perivascular wall tumors (PWTs) and, less frequently, fibrosarcoma, leiomyosarcoma, myxosarcoma, and liposarcoma. Therefore, in diagnostic practice a range of potential differential diagnosis is usually provided or a generic diagnosis of soft tissue sarcoma (STS) is made $[9,10]$.

The actual clinical advantage of sub-differentiating soft tissue sarcomas is questionable, due to their apparently similar biologic behavior. However, oversimplification may represent an obstacle in the discovery of specific treatments. Research on the definite differentiation and prognostic factors for each STS is essential for the development of novel specific treatment strategies, including molecular targeted therapies.

Several immunohistochemical (IHC) markers have been tested in order to provide differential diagnosis for STSs. In particular, S-100, oligodendrocyte transcription factor 2 (Olig2), glial fibrillary acidic protein (GFAP), neuron specific enolase (NSE) and nerve growth factor receptor (NGFR) were suggested as PNST markers. Moreover, calponin, desmin and alpha-smooth muscle actin ( $\alpha$-SMA) have been proposed as PW'T markers [9,11-14]. However, the results of such studies were poorly standardized and no definitive diagnostic criteria were established.

Recently, novel markers for therapeutic options have also been considered for MPNSTs. The epidermal growth factor receptor (EGFR), a $170-\mathrm{kDa}$ receptor tyrosine kinase (RTK) protein, was found to be expressed in $80 \%$ of human MPNST and in most murine MPNST cell lines. Furthermore, it was also demonstrated that the EGFR-STAT3 signaling pathway promoted the formation of MPNST $[15,16]$.

The aim of this study was to re-evaluate recently archived samples of canine cutaneous neoplasms initially diagnosed with STS-PNST based only on their morphology. In order to assess whether the phenotype was consistent with the tumor histological appearance a literature-based immunohistochemical panel was applied. Additionally, the expression of EGFR, a marker with potential therapeutic implications in MPNST, was assessed in canine STSs.

\section{MATERIALS AND METHODS}

A retrospective study was performed on archived cases submitted to the Pathology Service of the Department of Veterinary Medical Sciences, University of Bologna, between January 2011 and December 2014. Only canine cutaneous STS with a pre- 
existing diagnosis of PNST (as the primary diagnosis or among differential diagnoses) were included. None of them had previously undergone IHC analysis. The histologic diagnosis was made by different pathologists during their routine diagnostic activity. For each case, demographic information, including sex, age, breed, tumor location and tumor size were recorded.

Hematoxylin and eosin (HE) sections were re-evaluated separately by two pathologists (LM and RS) and graded according to Kuntz et al. (1997) [17]. Discordances were additionally re-examinated in order to achieve an agreement on the diagnosis.

For IHC analysis, a panel of 8 antibodies, including $\alpha$-SMA, calponin, desmin, S-100, GFAP, NSE, Olig2 and EGFR, was applied to $4 \mu \mathrm{m}$ serial tumor sections.

Endogenous peroxidase activity was blocked with $3 \% \mathrm{H}_{2} \mathrm{O}_{2}$; antigen retrieval is reported in Table 1 . Following overnight incubation at $4^{\circ} \mathrm{C}$, the primary antibody was revealed by a commercial avidin-biotin-peroxidase kit (Vectastain Elite ABC Kit, PK-6100, Vector Laboratories, Burlingame, CA, USA); 3,3' diaminobenzidine (DAB Chromogen/Substrate Kit K001, DS-4011-A, Diagnostic BioSystems, Pleasanton, CA, USA) was used as chromogen. Canine intestine ( $\alpha$-SMA, desmin), canine mammary gland (calponin), canine brachial plexus nerve (S-100, Olig2, GFAP, NSE) and canine squamous cell carcinoma (EGFR) were used as positive controls. Negative controls were obtained by omitting the primary antibody.

Table 1. Immunohistochemical antibody panel applied to 21 cases of canine soft tissue sarcomas

\begin{tabular}{|c|c|c|c|c|}
\hline Antibody & $\begin{array}{c}\text { Type } \\
\text { (catalog number) }\end{array}$ & Source & Dilution & Antigen retrieval \\
\hline $\begin{array}{l}\alpha \text {-smooth muscle actin } \\
(\alpha \text {-SMA })\end{array}$ & $\begin{array}{l}\text { Mouse monoclonal } \\
\text { 1A4 (M0851) }\end{array}$ & $\begin{array}{l}\text { Dako, Glostrup, } \\
\text { Denmark }\end{array}$ & $1: 450$ & $\begin{array}{l}\text { pH } 6 \text { citrate buffer } \\
\text { MWO } 750 \mathrm{~W} 10 \text { ' }\end{array}$ \\
\hline Calponin & $\begin{array}{l}\text { Mouse monoclonal } \\
\text { CALP (M3556) }\end{array}$ & $\begin{array}{l}\text { Dako, Glostrup, } \\
\text { Denmark }\end{array}$ & $1: 2000$ & $\begin{array}{l}0.05 \% \text { proteinase } \\
\text { K TB } 37^{\circ} \mathrm{C} 15^{\prime}\end{array}$ \\
\hline Desmin & $\begin{array}{l}\text { Mouse monoclonal } \\
\text { DE-R-11 (M0724) }\end{array}$ & $\begin{array}{l}\text { Dako, Glostrup, } \\
\text { Denmark }\end{array}$ & $1: 50$ & $\begin{array}{l}\text { pH } 6 \text { citrate buffer } \\
\text { MWO } 750 \text { W } 10^{\prime}\end{array}$ \\
\hline S-100 & $\begin{array}{l}\text { Rabbit polyclonal } \\
(760-2523)\end{array}$ & $\begin{array}{l}\text { Ventana, Tucson, } \\
\text { AZ, USA }\end{array}$ & Prediluted & $\begin{array}{l}\text { pH } 6 \text { citrate buffer } \\
\text { MWO } 750 \mathrm{~W} 10^{\prime}\end{array}$ \\
\hline $\begin{array}{l}\text { Oligodendrocyte } \\
\text { Lineage Transcription } \\
\text { Factor } 2 \text { (Olig2) }\end{array}$ & $\begin{array}{l}\text { Rabbit polyclonal } \\
\text { (AB9610) }\end{array}$ & $\begin{array}{l}\text { Merck-Millipore, } \\
\text { Billerica, MA, } \\
\text { USA }\end{array}$ & $1: 500$ & $\begin{array}{l}\text { pH } 8 \text { EDTA } \\
\text { buffer MWO } \\
750 \mathrm{~W} 10\end{array}$ \\
\hline $\begin{array}{l}\text { Glial fibrillary acidic } \\
\text { protein (GFAP) }\end{array}$ & $\begin{array}{l}\text { Rabbit polyclonal } \\
\text { (Z0334) }\end{array}$ & $\begin{array}{l}\text { Dako, Glostrup, } \\
\text { Denmark }\end{array}$ & 1:8000 & $\begin{array}{l}0.05 \% \text { trypsin } \\
\text { TB } 37^{\circ} \mathrm{C} 15\end{array}$ \\
\hline $\begin{array}{l}\text { Neuron specific } \\
\text { enolase (NSE) }\end{array}$ & $\begin{array}{l}\text { Mouse monoclonal } \\
\text { BBS/NC/VI-H14 } \\
(\mathrm{M} 0873)\end{array}$ & $\begin{array}{l}\text { Dako, Glostrup, } \\
\text { Denmark }\end{array}$ & $1: 1200$ & $\begin{array}{l}\text { pH } 6 \text { citrate buffer } \\
\text { MWO } 750 \text { W } 10^{\prime}\end{array}$ \\
\hline $\begin{array}{l}\text { Epidermal growth } \\
\text { factor receptor } \\
\text { (EGFR) }\end{array}$ & $\begin{array}{l}\text { Mouse monoclonal } \\
111.6 \text { (MS-378-P0) }\end{array}$ & $\begin{array}{l}\text { Thermo Fisher } \\
\text { Scientific, } \\
\text { Freemont, CA, } \\
\text { USA }\end{array}$ & $1: 100$ & $\begin{array}{l}\text { protease XIV } \\
\text { TB } 37^{\circ} \mathrm{C} 15 \text { ' }\end{array}$ \\
\hline
\end{tabular}

$\mathrm{MWO}=$ microwave oven; $\mathrm{TB}=$ thermostatic bath. 
Tumors were defined as positive in the presence of immunolabeling in more than $10 \%$ of neoplastic cells according to Ko et al. (2014) [14].

\section{RESULTS}

\section{Demographic information}

Twenty-one cases were included in the study. Nine dogs were mixed breed while 12 were purebred, the latter mostly represented by Boxer $(n=3)$, German shepherd $(n=3)$ and Labrador retriever $(n=2)$. The mean age was 10.4 years (range, 4.5-16.5 years). Ten of these cases were represented by intact males and the remaining 11 case by females, 5 of which were spayed. Tumors were located in the forelimbs $(n=5)$; hindlimbs $(n=7)$, head $(n=1)$ and trunk $(n=8)$, including in the perivulvar $(n=1)$, mammary $(n=1)$ and paravertebral region $(n=1)$. The mean tumor diameter was 4.8 $\mathrm{cm}$ (range, $0.5-12 \mathrm{~cm}$ ).

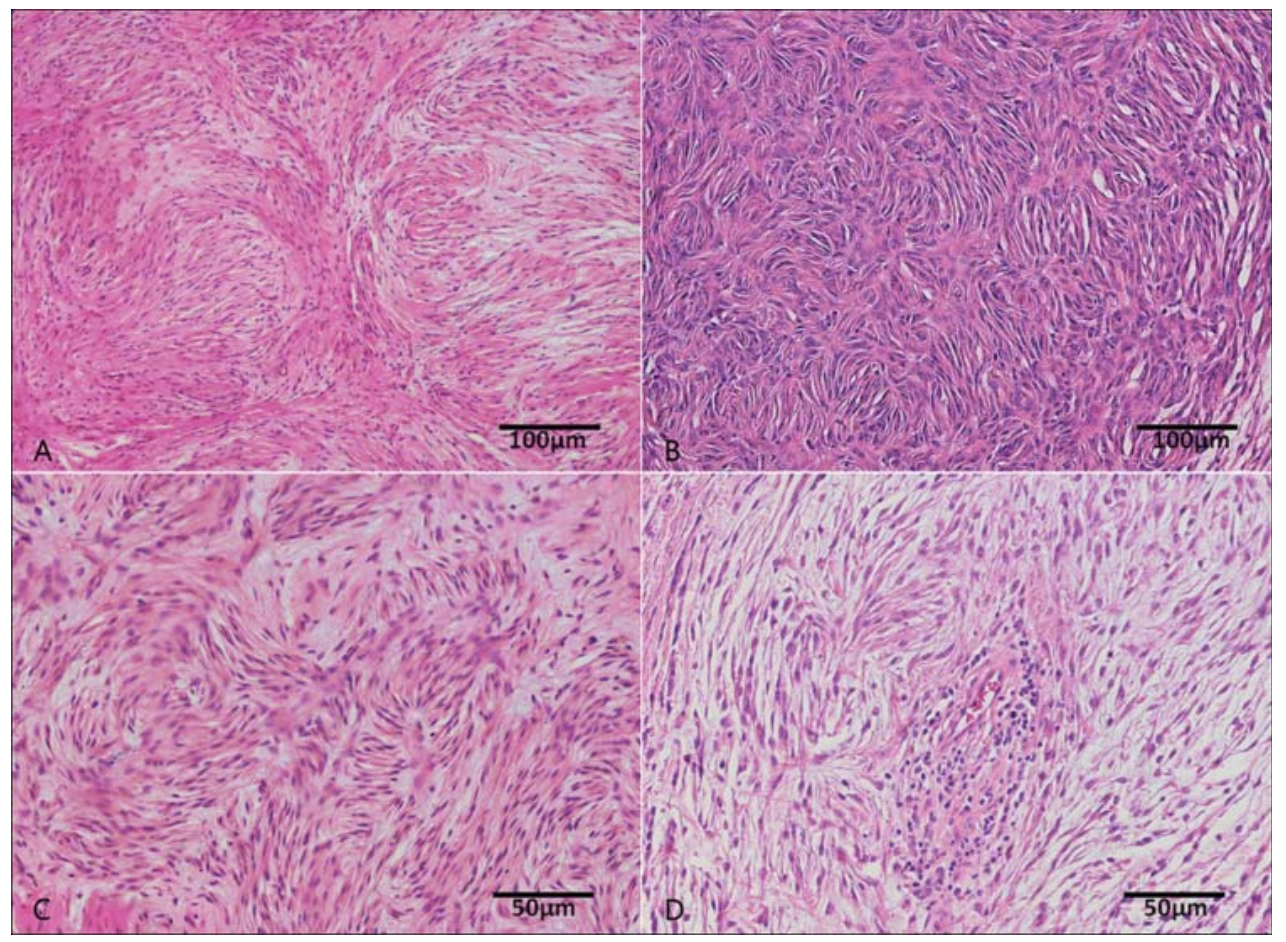

Figure 1. Histological growth pattern and cell features of different STS previously diagnosed as PNST. (A) Elongated spindle neoplastic cells arranged in bundles and interspersed in a collagen matrix. (B) Closely packed fusiform neoplastic cells arranged in a storiform pattern. (C) Fusiform neoplastic cells arranged in short rows and forming nuclear palisades. (D) Fusiform neoplastic cells arranged in whorls and interspersed in loose myxoid matrix. H\&E stain.

\section{Histology}

The microscopic examination revealed similar histologic appearance between all cases, with a variable alternation of highly-and poorly-cellular areas. The highly-cellular areas 
were composed by oval to spindle cells arranged irregularly in short bundles, palisades, storiform fascicles and concentric whorls. The poorly-cellular areas were characterized by fusiform neoplastic cells interspersed in loose fibrillary or myxoid matrix (Figure 1).

Two cases $(9.5 \%)$ were classified as grade I, $13(61.9 \%)$ as grade II and the remaining 6 cases $(28.6 \%)$ as grade III.

\section{Immunohistochemistry}

IHC results are detailed in Table 2. Fourteen cases (66.7\%) were positive for one or more muscular markers ( $\alpha$-SMA and calponin, 47.6\% each; desmin, $14.3 \%$ ). Of these tumors, none was positive for S-100, $5(35.7 \%)$ were positive for both NSE and Olig2, and $4(28.6 \%)$ were EGFR-positive. Within the 7 cases that resulted negative to the muscular markers, a positive labeling for S-100 was observed in one tumor $(14.3 \%)$; 3 cases $(42,8 \%)$ were positive for both NSE or Olig2, whereas 2 cases $(28.6 \%)$ were EGFR-positive. All cases were negative to GFAP.

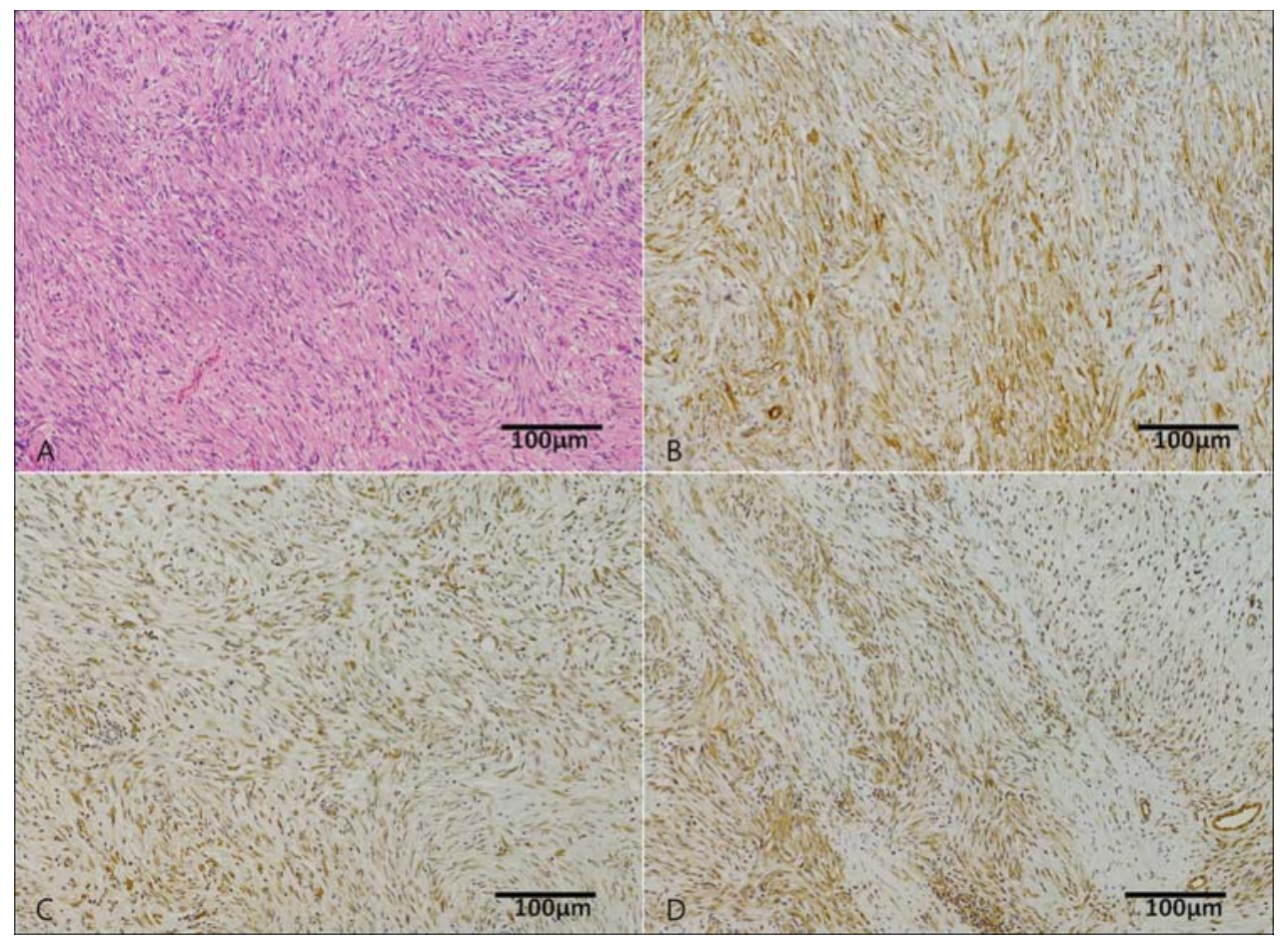

Figure 2. Histology and immunohistochemistry of a reclassified PWT. (A) Fusiform neoplastic cells arranged in short rows and forming nuclear palisades. (B) $\alpha$-SMA antibody: positivity of cytoplasm of neoplastic cells. (C) Calponin antibody: positivity of cytoplasm of neoplastic cells. (D) Olig-2 antibody: positivity of nuclei and cytoplasmic process of neoplastic cells but also vessels stained aspecifically positive. H\&E stain. 
Based on IHC results, the 14 tumors that resulted positive to muscular markers were classified as PWTs (Figure 2), the S-100 positive case was classified as PNST (Figure 3), whereas the other 6 tumors were classified as poorly-differentiated STSs.

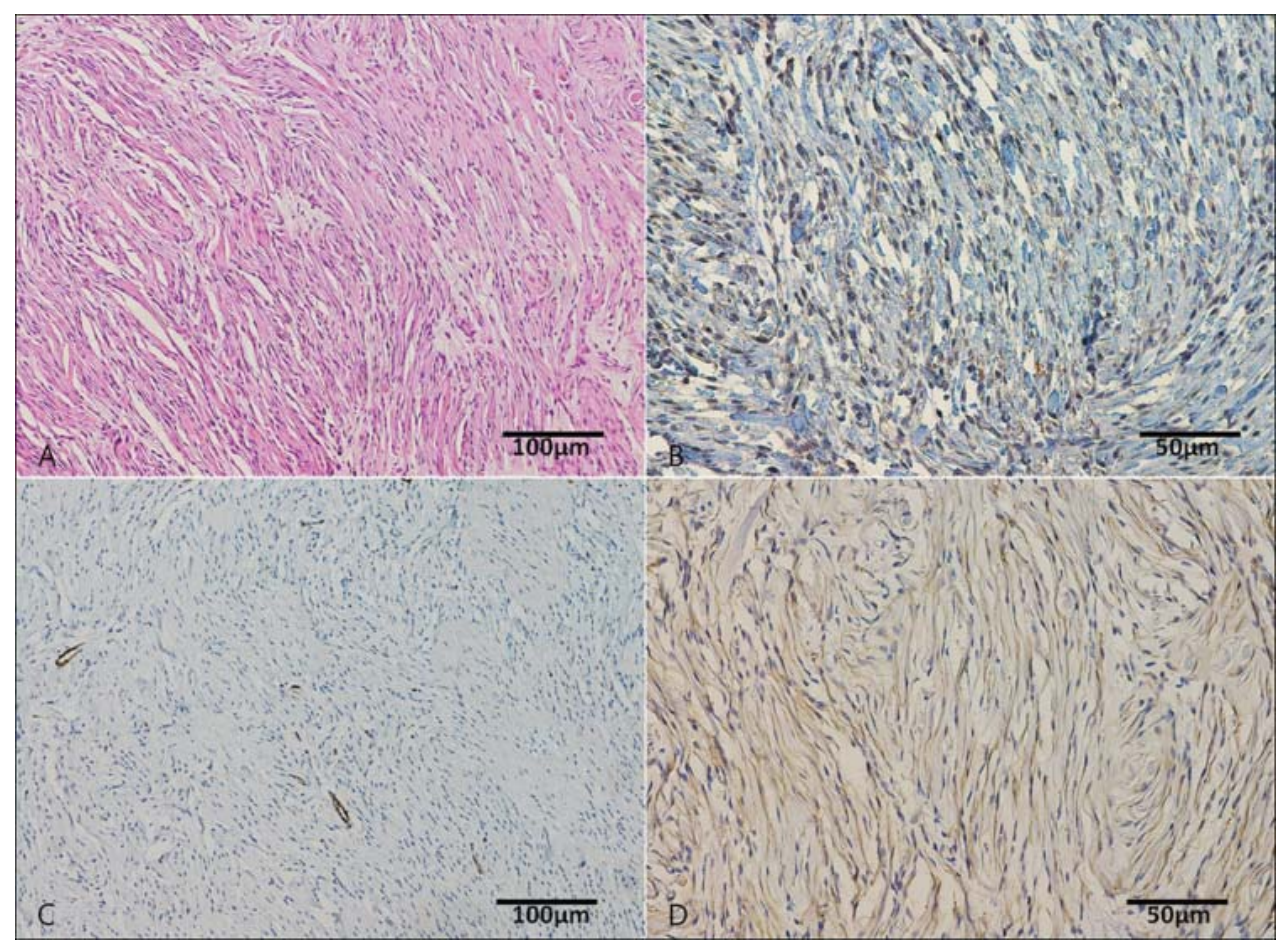

Figure 3. Histology and immunohistochemistry of an already classified PNST. (A) Elongated spindle neoplastic cells arranged in bundles and interspersed in a collagen matrix. (B) S100 antibody: positivity of nuclei and cytoplasmic process of neoplastic cells. (C) $\alpha$-SMA antibody: negativity of neoplastic cells while vessels stained specifically positive. (D) Olig-2 antibody: positivity of nuclei and cytoplasmic process of neoplastic cells. H\&E stain.

At the second histological evaluation, no unique morphological feature was observed within each of the three groups. All the 6 grade III tumors belonged to the PWT group, whereas the only PNST was grade I.

\section{DISCUSSION}

The distinction of PNSTs from perivascular wall tumors by histopathology is not currently based on clear morphological differences. Several authors suggest that the presence of nerve fibers within the tumor may be a useful diagnostic indicator. Nevertheless, it is generally accepted that occasional small nerves may be seen in subcutaneous spindle cell tumors and that they are not necessarily related to the tumor itself $[1,4,13,14,18]$. Therefore, the true incidence of canine PNST and their biologic behavior are yet to be determined, due to poorly established diagnostic criteria. 
Currently, the degree to which STSs types behave similarly is unknown. Histological diagnosis is not essential for the clinical management of these tumors, however it could help understanding the prognosis. Most STSs are in acral location, and surgical excision at that level is intended to be marginal. Thus, understanding and differentiating their biologic behavior might be useful in the post-operative setting to evaluate the need for adjuvant treatments (e.g. radiotherapy or chemotherapy). The first step in detecting potential differences is to define methods for an accurate classification. Although some recent studies improved the classification of canine PWTs [11,19], there is still considerable overlap of histologic diagnosis between STS types.

The aim of the present study was to assess whether a histological re-evaluation, followed by a comprehensive immunohistochemical analysis, could be useful for obtaining a more accurate diagnosis in a subgroup of STSs consistent with a PNST morphology.

Although plenty of different antibodies have been tested in the past fifteen years to help the identification of canine PNSTs [9,12-14], no specific immunohistochemical marker has been identified because of the heterogeneous data that emerged from these studies. For this reason a wide panel of reagents is generally used. According to the previously published studies, PNST appears to be primarily a "diagnosis of exclusion", with the first distinguishing feature being the negativity to muscle cell markers. Indeed, immunoreactivity for $\alpha-$ SMA and desmin is a quite unusual finding in human PNSTs, and specifically it was described in one case out of 135 PNSTs [20] and 75 PNSTs [21], while it was never documented for dogs [9,12]. A study on PWT subclassification reports positivity to muscular markers and negativity to S-100 and GFAP as reliable immunohistochemical features to distinguish PWTs from PNSTs [11]. In the present study, no overlapping was found between immunoreactivity to muscular markers and S-100, which led us to set reclassification based only on those markers.

S-100 proteins are normally present in cells derived from the neural crest (Schwann cells and melanocytes). In human medicine, the expression of S-100 is used to differentiate between neural and non-neural origin spindle cell tumors [22]. In feline and equine PNSTs this marker has been proven to be useful in the diagnosis [23,24]. However, S-100 immunoreactivity in canine MPNST may be unrewarding, likely because these neoplasms can be composed of various cell types other than Schwann cells, including perineural cells, or perineural or endoneural fibroblasts [12-14]. In our case series, tumor cells positive to S-100 were observed only in one case, possibly due to either a low PNST incidence or a poor sensitivity of this marker.

GFAP is an intermediate filament protein found in glial cells such as astrocytes and ependymal cells, in Schwann cells, enteric glial cells and satellite cells of human sensory ganglia [25]. In humans, GFAP expression is more frequently found in benign (33\%) rather than MPNST (7\%) [26]. In dogs, Chijiwa et al. (2004) reported a 35\% GFAP expression (18\% in MPNSTs and 67\% in BPNSTs) [12]. Another study reports only one case of scattered GFAP expression within the cytoplasm of some large 
multinucleated cells [13]. Since no positive case was found in our series, we cannot provide a significant contribution on the diagnostic utility of this marker.

NSE has also been used to demonstrate the neuroectodermal origin of neoplastic cells $[3,27]$. However, the application of this marker has been limited because of the frequent nonspecific background staining. A similar tendency was observed in the present study, since a diffuse cytoplasmic positivity was also commonly detected in PWTs and in mesenchymal cells from the peritumoral stroma.

Olig2 is a marker of the oligodendroglial lineage and of some central nervous system progenitors [28]. In a recent study, Olig2 appeared to be a promising diagnostic marker for malignant PNSTs allowing the differentiation between PNSTs and PWTs with a positivity of $90 \%$ and $20 \%$, respectively [9]. However, in the present study Olig2 results were quite disappointing, with extensive labelling of normal vessels walls and a $40 \%$ positivity recorded among PWTs.

The applied IHC panel did not allow a definitive differentiation between PWT and PNST in 6 cases. According to recent studies a small subgroup of PWTs with equivocal morphology and lack of specific immunohistochemical markers may exist, so that in the case of extensive immunohistochemical negativity a definitive diagnosis may not be reached. In order to provide clarity, further IHC studies should be performed in the presence of a definitive diagnosis based on ultrastructural investigation [29].

Among other neural markers that have not been applied in the present study, NGFR and protein gene product 9.5 (PGP 9.5) may be worth further consideration [9]. Additionally, because Schwann cells differ from most PWT cells for the presence of a basal membrane, laminin and collagen IV have been proposed as PNST markers. Nevertheless, their sensitivity is lower in MPNSTs, where the basal lamina may be scant and focal, and positivity is limited to the tumors with a primary Schwann cell component [13]. Among PW'Ts, also glomus tumors have a basal lamina [4].

Recently, several growth factors have been tested on canine PWTs in order to propose alternative therapeutic options for these tumors. The pathways with the highest expression were those mediated by RTK, including VEGFR, PDGFR $\beta$ and FGFR [19]. To the authors' knowledge, this is the first time that EGFR expression is investigated in a cohort of canine STSs. The observed positivity in one fourth of the cases provides further evidence that multiple RTK blockade may represent a promising strategy for the local control of these tumors.

In summary, the IHC panel employed in the present study allowed reclassification of $75 \%$ of the cases previously diagnosed as potential PNST by histology alone as PWTs, thereby showing a tendency to overdiagnose PNST. A PNST phenotype could only be confirmed in 1 out of 21 cases. However, there may have been an underestimation due to the poor differentiation of the remaining 5 cases. Indeed, negativity to smooth muscle markers in the presence of a wavy cytoplasm, nuclear palisades, fascicles intersecting at sharp angles and presence of poorly cellular areas embedded in mucopolysaccaridic matrix, may suggest a diagnosis of PNST, even in 
the absence of a clear S-100 positivity. Other neuronal markers, such as NSE and Olig2, have not demonstrated a diagnostic value in this study, whereas the utility of GFAP could not be ascertained due to absence of positive cases.

Further studies are needed to confirm the origin of these tumors and to study the cellular pathways involved in their proliferation and invasion.

\section{Authors' contributions}

All authors collaborated in the design of the study. RS and SS drafted the manuscript and carried out immunohistochemistry. RS and LM re-evaluated separately the histological sections. GB contributed to the incisive evaluation of the final version of the manuscript. All authors read and approved the final manuscript.

\section{Declaration of conflicting interests}

The author(s) declared no potential conflicts of interest with respect to the research, authorship, and/or publication of this article.

\section{REFERENCES}

1. Hendrick MJ, Mahaffey EA, Moore FM, Vos JH, Walder EJ Hendrick MJ, Mahaffey EA, Moore FM, Vos JH, Walder EJ: World Health Organization, International Histological Classification of Tumors of Domestic Animals, Histological Classification of Mesenchymal Tumors of Skin and Soft Tissues of Domestic Animals. Second Series, Armed Forces Institute of Pathology American Registry of Pathology, Washington, DC; 1998, 25-27.

2. Koestner A, Bilzer T, Fatzer R, Schulman FY, Summers BA, Van Winkle TJ: World Health Organization, International Histological Classification of Tumors of Domestic Animals, Histological Classification of Tumors of the Nervous System of Domestic Animals. Second Series, Armed Forces Institute of Pathology American Registry of Pathology, Washington, DC; 1999, 36-38.

3. Koestner A, Higgins RJ: Tumors of the nervous system. In: Tumors in domestic animals. Meuten DJ (ed). 4th, Iowa State Press; 2008, 697-738.

4. Gross TL, Ihrke PJ, Walder EJ, Affolter VK: Neural and Perineural Tumors. In: Skin Diseases of the Dog and Cat. Oxford, United Kingdom: Blackwell Science Ltd; 2005, 786-796.

5. Piña-Oviedo S, Ortiz-Hidalgo C. The normal and neoplastic perineurium. Adv Anat Pathol 2008, 15:147-164.

6. Bergmann W, Burgener IA, Roccabianca P, Rytz U, Welle M.: Primary splenic peripheral nerve sheath tumour in a dog. J Comp Pathol 2009, 141:195-198.

7. Brehm DM, Vite CH, Steinberg HS, Haviland J, van Winkle T: A retrospective evaluation of 51 cases of peripheral nerve sheath tumors in the dog. J Am Anim Hosp Assoc 1995, 31:349-359.

8. Park JW, Woo GH, Jee H, Jung DW, Youn HY, Choi MC, Kim DY: Malignant peripheral nerve sheath tumour in the liver of a dog. J Comp Pathol 2011, 144:223-226. 
9. Suzuki S, Uchida K, Nakayama H: The effects of tumor location on diagnostic criteria for canine malignant peripheral nerve sheath tumors (MPNSTs) and the markers for distinction between canine MPNSTs and canine perivascular wall tumors. Vet Pathol 2014, 51:722-736.

10. Dennis MM, McSporran D, Bacon NJ, Schulman FY, Foster RA, Powers BE: Prognostic factors for cutaneous and subcutaneous soft tissue sarcomas in dogs. Vet Pathol 2011, 48:73-84.

11. Avallone G, Helmbold P, Caniatti M, Stefanello D, Navak RC, Roccabianca P: The spectrum of canine cutaneous perivascular wall tumors: morphologic, phenotypic and clinical characterization. Vet Pathol 2007, 44:607-620.

12. Chijiwa K, Uchida K, Tateyama S: Immunohistochemical evaluation of canine peripheral nerve sheath tumors and other tissue sarcomas. Vet Pathol 2004, 41:307-318.

13. Gaitero L, Añor S, Fondevila D, Pumarola M: Canine cutaneous spindle cell tumours with features of peripheral nerve sheath tumours: a histopathological and immunohistochemical study. J Comp Pathol 2008, 139:16-23.

14. Ko S-B, Song K-O, Kang S-C, Kim J-H: Cutaneous peripheral nerve sheath tumors in 15 dogs. Korean J Vet Res 2014, 54:7-12.

15. Holtkamp N, Malzer E, Zietsch J, Okuducu AF, Mucha J, Mawrin C, Mautner VF, Schildhaus HU, von Deimling A: EGFR and erbB2 in malignant peripheral nerve sheath tumors and implications for targeted therapy. Neuro Oncol 2008, 10:946-957.

16. Wu J, Patmore DM, Jousma E, Eaves DW, Breving K, Patel AV, Schwartz EB, Fuchs JR, Cripe TP, Stemmer-Rachamimov AO, Ratner N: EGFR-STAT3 signaling promotes formation of malignant peripheral nerve sheath tumors. Oncogene 2014, 33:173-180.

17. Kuntz CA, Dernell WS, Powers BE, Devitt C, Straw RC, Withrow SJ: Prognostic factors for surgical treatment of soft-tissue sarcomas in dogs: 75 cases (1986-1996). J Am Vet Med Assoc, 1997, 211:1147-1151.

18. Sawamoto O, Yamate J, Kuwamura M, Hagiwara R, Kurisu K: A canine peripheral nerve sheath tumour including peripheral nerve fibers. J Vet Med Sci 1999, 61:1335-1338.

19. Avallone G, Stefanello D, Boracchi P, Ferrari R, Gelain ME, Turin L, Tresoldi E, Roccabianca P: Growth Factors and COX2 Expression in Canine Perivascular Wall Tumors. Vet Pathol 2015, 52:1034-1040.

20. Dundr P, Povysil C, Tvrdik D: Actin expression in neural crest cell-derived tumors including schwannomas, malignant peripheral nerve sheath tumors, neurofibromas and melanocytic tumors. Pathol Int 2009, 59: 86-90.

21. Boland JM, Colby TV, Folpe AL: Intrathoracic peripheral nerve sheath tumors - a clinicopathological study of 75 cases. Human Pathol 2015, 46: 419-425.

22. Scheithauer BW, Woodruff JM, Erlandson RA: Tumors of the peripheral nervous system. In: Atlas of Tumor Pathology. Armed Forces Institute of Pathology American Registry of Pathology, Washington, DC, Third Series, fascicle 24; 1999, 303-369.

23. Schulman FY, Johnson TO, Facemire PR, Fanburg-Smith JC: Feline peripheral nerve sheath tumors: histologic, immunohistochemical, and clinicopathologic correlation (59 tumors in 53 cats). Vet Pathol 2009, 46:1166-1180.

24. BogaertL, Heerden MV, Cock HE, Martens A, Chiers K: Molecularandimmunohistochemical distinction of equine sarcoid from schwannoma. Vet Pathol 2011, 48:737-741.

25. Jessen KR, Thorpe R, Mirsky R: Molecular identity, distribution and heterogeneity of glial fibrillary acidic protein: an immunoblotting and immunohistochemical study of Schwann cells, satellite cells, enteric glia and astrocytes. J Neurocytol 1984, 13:187-200. 
26. Gray MH, Rosenberg AE, Dickersin GR, Bhan AK: Glial fibrillary acidic protein and keratin expression by benign and malignant nerve sheath tumours. Hum Pathol 1989, 20:1089-1096.

27. Enzinger FM, Weiss SW: Soft Tissue Tumours. Mosby, St. Louis, Missouri, USA 2nd ed., 1988, 719-815.

28. Binder E, Rukavina M, Hassani H, Weber M, Nakatani H, Reiff T, Parras C, Taylor V, Rohrer $\mathrm{H}$ : Peripheral nervous system progenitors can be reprogrammed to produce myelinating oligodendrocytes and repair brain lesions. J Neurosci 2011, 31:6379-6391.

29. Palmieri C, Avallone G, Cimini M, Roccabianca P, Stefanello D, Della Salda L: Use of electron microscopy to classify canine perivascular wall tumors. Vet Pathol 2013, 50:226233.

\title{
REKLASIFIKACIJA 21 TUMORA OVOJNICA PERIFERNIH NERAVA PASA (PNST) UPOTREBOM IMUNOHISTOHEMIJSKOG PANELA PREMA PREPORUKAMA IZ LITERATURE
}

\author{
SIRRI Rubina, SABATTINI Silvia, BETTINI Giuliano, MANDRIOLI Luciana
}

Cilj studije je bio da se obavi re-evaluacija arhiviranih uzoraka sarkoma mekih tkiva (soft tissue sarcomas, eng. -SSTs) koji su morfološki odgovarali tumorima ovojnica perifernih nerava pasa (peripheral nerve sheath tumors, eng. - PNSTs). U svakom pojedinačnom slučaju, primenjen je imunohistohemijski panel koji je uključivao $\alpha$-SMA, calponin, desmin, S-100, GFAP, NSE i Olig2, a u cilju procene da li je fenotip bio konzistentan sa histološkim nalazom na tumoru. Pored toga, obavljena je i evaluacija EGFR, koji ima potencijalne terapijske implikacije u odnosu na PNST. Studijom je obuhvaćen 21 tumor. Četrnaest slučajeva $(66,7 \%)$ je bilo pozitivno na najmanje jedan marker mišićnog tkiva pri čemu je obavljena reklasifikacija kao perivaskularni tumori (perivascular tumors, eng.- PVTs). Pozitivno bojenje sa S-100 bilo je uočeno kod jednog tumora $(4,8 \%)$ pa je taj uzorak klasifikovan kao PNST. Ostalih 6 tumora, su klasifikovani kao slabo diferentovani STS. U sve tri grupe, nisu uočene jedinstvene histopatološke osobine. NSE i Olig2 obeležavanje nije bilo specifično i nije moglo da se upotrebi u dijagnostičke svrhe. GFAP je bio negativan u svakom slučaju. Šest uzoraka tumora $(28,6 \%)$ su bili pozitivni na EGFR, uključujući i PNST. Čak i posle primene šireg imunohistolohemijskog panela, razlikovanje između PNST i PVT i dalje predstavlja značajan problem i izazov za patologe. Konačno, nije moguće svrstavanje tumora u podgrupe, samo na osnovu svetlosne mikroskopije. 